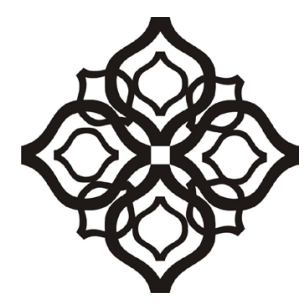

Shirkah

Journal of Economics and Business 


\section{Shirkah}

Journal of Economics and Business

Vol. 4, No. 2, May-August 2019

ISSN: 2503-4235 (p); 2503-4243 (e)

\section{Editor in Chief}

Fitri Wulandari

\section{Managing Editor}

Jasanta Peranginangin

\section{Editorial Boards}

AAbdul Azim Islahi,

Islamic Economics Institute, King Abdulaziz University, Saudi Arabia

Abu Umar Faruq Ahmad,

UBD School of Business and Economics Universiti, Brunei Darussalam

Cedomir Nestorovic,

ESSEC Business School Asia Pacific, Singapore

Johan Fischer,

Department of Social Sciences and Business Roskilde Universitetscenter, Denmark Muhamed Zulkhibri,

Islamic Research and Training Institute, Islamic Development Bank, Saudi Arabia M. Kabir Hassan,

Department of Economics and Finance, University of New Orleans, United States Musa Asy'arie,

Faculty of Islamic Economics and Business, IAIN Surakarta, Indonesia

Nunung Nurul Hidayah,

Aston Business School, Aston University, Birmingham, United Kingdom

Saim Kayadibi,

Department of Economics, Kulliyyah of Economics and Management Science,

International Islamic University Malaysia, Malaysia

Shaikh M Ghazanfar,

Departement of Economics, University of Idaho, Russian Federation 
Sigit S. Wibowo,

Department of Management, Faculty of Economics and Business, Universitas Indonesia, Indonesia

Vihang R. Errunza,

Desmarais Global Finance Research Centre, Desautels Faculty and Management, McGill University, Canada

\section{Assistant to Editor}

M. Endy Saputro

M. Zainal Anwar

Shirkah Journal of Economics and Business is a peer-reviewed journal published three times a year (January-April, May-August and September-December) by Faculty of Islamic Economics and Business, Institut Agama Islam Negeri (IAIN) Surakarta Central Java, Indonesia. The main objective of Shirkah is to offer an academic space of exchange ideas and initiate the increase number of qualified article produced by postgraduate students, practitioners and academicians.

\section{Editorial Office}

Ruang Jurnal Shirkah

Lantai Dasar, Sayap Barat, Fakultas Ekonomi dan Bisnis Islam, IAIN Surakarta

Jln. Pandawa No. 1, Kartasura, Sukoharjo, Jawa Tengah Kode Pos. 57168

Phone (+62271) 781516 Fax: (+62271)782336

E-mail: shirkahjournal@iainsurakarta.ac.id; shirkahiainsurakarta@gmail.com Website: http://shirkah.or.id/ 


\section{Shirkah}

Journal of Economics and Business

Vol. 4, No. 2, May-August 2019

ISSN: 2503-4235 (p); 2503-4243 (e)

\section{Table of Contents}

\section{Articles}

Abd Hannan

Santripreneurship and Local Wisdom Economic Creative of Pesantren Miftahul Ulum

Muh. Salahuddin

Nurhilaliati

Zaenal Arifin

Entrepreneurship and Economics of Pesantrens in Lombok Island

Abdul Jalil

Alumni Networks and Economic Reinforcement in Pesantren

Ummussabri

Jehan Maya Zayanie

Ahsana Fitria

Rosidatul Kamariah

Bank Wakaf Mikro and Creative Economics in Pesantren Buntet

Farihatul Qamariyah

Muslim Business Women in Indonesia

Fachrurazi

Dwi Srya Atmaja

Zaenuddin Hudi Prasojo

Muslim Businessmen and Chinese Economics in Singkawang 


\title{
Alumni Networks and Economic Reinforcement in Pesantren Ummussabri
}

\author{
Abdul Jalil \\ Department of Cultural Science, Universitas Halu Oleo, Kendari \\ abduljalil.uho@gmail.com
}

\begin{abstract}
This study discusses the alumni network supporting the economic development of an Islamic institution, namely pesantren. In general, the strong alumni networks lead to strengthen the successful economic sector in the pesantren, since the alumni have sense of belonging to pesantren. This study focuses on how alumni network contributes significantly to the development of business units in Pesantren Ummussabri, Kendari. Doing participatory observation and in-depth interview, the study had been conducted in Pesantren Ummusabri, particularly in Empang 99 Paleppo unit. Such information had been gathered from administrator for pesantren's business division, alumni coordinator and some informants of Empang 99 Paleppo business unit. This study elucidates that strong pesantren alumni network can improve the pesantren creatively. It clearly can be seen from how the alumni, who have successfully occupied important positions in the government, have established Empang 99 Paleppo.
\end{abstract}

Keywords: alumni network, pesantren, creative economics, Kendari

\section{Introduction}

Pesantren Ummussabri is one of pesantrens locating in Kendari city, Southeast Celebes, Indonesia. In the beginning, this pesantren was established as a response of the strong animism and dynamism embraced by surrounding society. The community leaders of Kendari had transformed this condition into more Islamic way of life, by establishing Pesantren Ummusshabri. Another initiative to establish the pesantren came from Gabungan Usaha Perbaikan Pendidikan Islam or GUPPI (Joint Effort for 
Islam Education Improvement), later during Muktamar VIII in Jakarta changed into Gabungan Usaha Pembaharuan Pendidikan Islam or GUPPI (Joint Effort for Islamic Education Reformation). The name Ummusshabri was chosen because its founders admired a santri figure in Kendari region. Linguistically, the word "Ummusshabri" means high patience. Along with such the name, Islam male and female youths educated in this pesantren are expected to have high patience for building this beloved country, particularly in Southeast Celebes region. One of pesantren's founders today is $\mathrm{KH}$. Mursidin, a charismatic figure who becomes a great imam (Islamic leader of communal prayer) in the great mosque of al-Kautsar and alAlam Kendari. Education held in Pesantren Ummusshabri uses integrative curriculum system, holding education with Ministry of Religion's curriculum, national education curriculum, and pesantren's curriculum.

People living in Kendari City come from Buton, Muna, Moronene, and Tolaki, which called native ethnics. In addition, many people coming from surrounding areas also live in this region: Bugis, Bajo, Makassar, Javanese, and Sundanese ethnics. Even, there are still other ethnics such as Toraja and Balinese (Jalil, 2017). Based on demographic data, North Sulawesi belongs to a region which is vulnerable to ethnic, racist, and religious issues. Considering this fact, the pesantren has always inculcated tolerance through the sustainable building for santris to educate them understanding such condition prudently and wisely. Amid such condition and situation, Pesantren Ummusshabri was present in South East Celebes to answer those problems. The strategic location of pesantren, in the middle of Kendari city, also contributes to creating more peaceful community life order. In addition, this pesantren is expected to be an agent to spread peace.

Any private pesantren or institution cannot be sustaining when it cannot suffice its daily operational needs. One of models applied in the beginning as the basis to strengthen this institution is formal education, 
or madrasah at ibtidaiyyah, tsanawiyyah, and aliyah level. Through the management's hard work, some strategic measures have been taken: conducting road show or visiting some local governments in islands, including Buton and Muna. This form of cooperation with local government is manifested into the administration of full scholarship to local youths in order to enable them to study in the Pesantren Ummussabri; while to get general science, in addition to religious science, by attending madrasah held in pondok pesantren. Besides, Kendari City government, Gabungan Usaha Pembaharuan Pendidikan Islam (GUPPI) and alumni contribute to the development of Pesantren Ummussabri.

Several business units have been established to support the sustainable future of pesantren. Those business units are: Koperasi Pondok Pesantren (Kopontren/ pesantren cooperation) Ummussabri Kendari and kantin dalam (internal canteen). These two businesses are the ones managed directly by pesantren, while the ones which have not been managed directly by pesantren are stall rental (kantin santri $R-Q$ "Halal \& Toyib" and batagor siomay Bandung), shophouse building rental (ruko "Kamboy" foto copy and ATK/Gerai Transaksi Online, ruko "YG-Young Generation", ruko "Ummy Collection'), and some other businesses. In the pesantren's economic activity development plan, some community economic centers have been established: food stall (empang) named Paleppo '99 Ummussabri; this business has been established based on the alumni of Pesantren Ummussabri's larger investment. This study discusses further on the strategy of Ummussabri's alumni network in strengthening creative economics of the pesantren.

This research took place in the Pesantren Ummussabri, with its business unit being the object of research. The business unit of pesantren is divided into two: the one managed directly by pesantren and the one not, meaning that the pesantren prepares the building only, and then 
other people, generally constituting the alumni of pesantren utilize it by means of leasing it. 'Paleppo '99' business unit was selected because this unit was leased by an informant by keep putting forward the complete infrastructures. The land formerly inundated with water during rainy season is utilized to be food stall area designed to be a fishing place gives added-value. The environment becomes clean and healthy, and gives more educative value. Institutionally, the pesantren can be socialized by itself. Such informants were selected using purposive sampling technique, in which the informants selected were considered as capable of giving indepth interview on pesantren management, particularly business unit management. The informants of research consisted of La Hamiku and Abdul Makruf as key informants, and Istiqomah, Muli, Zakiyah, Fiah, and Jajang as other important informants.

\section{Studying Pesantren}

Much have been written on pesantren as Suharti and Ferrinela's (2012) who show that pesantren traces on alumni routinely to find out the change of and the need for graduates' capability corresponding to the complex practical world through alumni's opinion. Azizah (2014) reveals that the eco-protection based economic business activities in pesantren can be the basis of social change in the society. Furthermore, Mu'ammar (2014) discusses that pesantren has been the most reliable center for Islamic studies. Religious education activity in the pesantren has been considered as a space for knowledge transfer and worshiping practices, at the same time it promotes tawassuth (moderation) and tawazun (togetherness) values. Isbah (2016) explains that pesantren plays its role in contributing significantly to the pesantren's prosperity and welfare. Meanwhile, Trisnawati (2017) attempts to examine human resources (HR) in the pesantren and how the human resources improve the pesantren. 
Mursyid (2011) explicates that in sharpening its role within community, the pesantren should upgrade their action to face free market economic progress and sharia economics challenges. Nadzir (2015) finds that the pesantren as an integral part of community has responsibility for empowering community in any sectors including economic sector. It is in accordance with Fauzi's study which interprets local value of pesantren as the core value of Islamic economic development. In social practice theory, the internalization of social value has been interpreted to be social capital in realizing Islam economic behavior. Furthermore, Lugina (2017) justifies that pesantren has been established on the initiatives of community leader. As a cultural institution, the pesantren has autonomous strategic in transforming community's social life. Since 1970s, this institution not only served as religious education institution but also developed into the reposition attempt in alleviating such community problems as economics, social, and politics. Bawono (2018) focuses largely on values implemented by pesantren on creative economics within community.

This study emphases more on the development of business units in the Pesantren Ummussabri using the alumni network which most of them are still connected and involved in cooperation (koperasi). Some of them become tenant of shophouse provided by the pesantren. In general, shophouse tenants are alumni of the pesantren, but there are some other tenants having no relation to the pesantrens' big family which has been given special price because their children study in pesantren environment. They are considered as family or having close relation to the Pesantren Ummussabri's big family. As such, this study is different from the creative economic model existing in pesantrens. 


\section{Strengthening Business in the Pesantren}

As aforementioned, many businesses have been initiated by the pesantren, either fully managed or in partnership through utilizing land or stall that has been leased by the public in one-year period or longer. This mechanism relieves the second party/lessee's burden, and facilitates the management of pesantren to conduct evaluation. This part analyzes one potential business unit as the strongest support of pesantren's economics. In addition to business unit, there is also a prospective education unit, the management of which is returned to education directly, from the management to the need for the wage payment for human resource, including teachers and educator.

There are such business units of pesantren as "canteens inside the pesantren". There are eight canteens, with typical products sold, from nasi ayam (chicken rice), opor ayam (chicken dish cooked with coconut cream and various spices), nasi kuning (yellow rice), gado-gado (Javanese salad) and gorengan (fried food), bakso (meat ball), bubur ayam (chicken porridge), and teh poci/minuman (beverage). They lease the stall from the pesantren with leasing cost of IDR 9,000,000 per year for respective canteens. The canteens open from 06.30 a.m. - 05.00 p.m. local time. Terminology "canteens inside pesantren" should be confirmed to distinguish it from the canteens not managed directly by the pesantren, for an example "Canteen Santri R-Q Halal Toyib which is leased by one of alumni, Mrs $\mathrm{Hj}$. Nuraini. In addition to the canteens inside pesantren, the business unit which managed directly by pesantren is Koperasi Ummussabri Kendari.

There are some business units which have not been managed directly by the pesantren. It includes shophouse for which the pesantren leases four buildings with the same measure, including the one resided by Koperasi Ummussabri Kendari. Meanwhile, the three shophouses are resided by Kamboy Store, YG-Your Generation, and Ummy Collection Store. Each of 
these shophouses has a building in $5 \times 19$ meter dimension with the front yard in $5 \times 12$ meter dimension. As such, totally the building is 20 -meter width and 31-meter length. It belongs to business unit not-fully managed or not-directly managed by pesantren, but contributing considerably to pesantren because it has been managed by the pesantren alumni, for example Sea Food Paleppo' 99 Kendari. This business unit has been leased by an alumnus named La Rahama. This food stall is $50 \times 50$-meter width, with leasing cost of IDR 50,000,000/year. Several business units have run and contributed to the pesantren development as they yield income including, among others, the stall leased for beauty salon business with leasing cost of IDR 12,000,000 per year. The one leasing stall for beauty salon business is the parents of one of students in the Pesantren Ummussabri. This business unit which has not been managed directly by the pesantren are siomay and batagor Bandung seller for which have leased IDR 9,000,000 per year.

The educational institutions held in the Pesantren Ummussabri consists of several levels from early age child education (PAUD) with 150 students, kindergarten (raudlatul athfal) with 80 students, madrasah ibtidaiyyah (MI/Elementary School) with 120 students, madrasah tsanawiyyah (MTs/ Junior High School) with 600 students, to madrasah aliyah (MA/ Senior High School) with 300 students. Total income coming from this education institution is IDR 3,000,000,000 (three billion rupiahs). Meanwhile, the expenditure is reverted to the school's needs including wage payment for non-civil servant teachers. It means that the pesantren does not use the income because each of institutions is authorized to conduct full management, despite periodical report to the foundation.

La Hamiku said that the structure of the foundation has changed since 2014, from the leader of the pesantren into syaikhul ma'had under KH. Mursidin's leadership (as senior alumni), the lessee of a shophouse in 
front of pesantren Ummy Collection shophouse, and the great imam in the great mosque (Masjid Raya) al-Kautsar and mosque Al-Alam in Kendari city. This Syaikhul Ma'had supervises two divisions: firstly, education and kepesantrenan (anything related to the pesantren) for which Ustadz Zainul Mustamin as the director; and secondly, business charity division for which La Hamiku as the director. Syaikhul Ma'had_leadership has run for two periods: 2015-2018 and 2019-2023. In addition, there is Child Social Welfare Institution (LKSA) unit under Business Charity Division, containing the element of donator fund management. There are about 80 students attending training in LKSA or other units in the pesantren. They are prioritized to get tuition fund from permanent donor and to obtaine scholarship or grant.

The table (appendix 1) shows that the income of indirect business unit is IDR 274,000,000,- per year and that from education institution is IDR 3,000,000,000 (three billions rupiah). Indirect business intends to lease the land and the building such as shophouse. Otherwise, direct business is the one which managed directly by the pesantren, such as canteen in the koperasi pesantren. Furthermore, the table (appendix 1) can be described as follows. Firstly, Kantin Santri (canteen for santri) R-Q Halal Toyib opens from 07.00 a.m. to 02.00 p.m. at local time which has taken care by an alumnus of pesantren, Istiqomah. This stall sells any types of rice-based food such as 55 portions of yellow rice with fish/egg, each of which costs IDR 7,000, 30 portions of nasi ayam geprek, each of which cost IDR 12,000, and 4 portions of crispy chicken rice, each of which costs IDR 15,000. Secondly, batagor street seller with the lowest sale volume of IDR 800,000 per day, frequently reaching IDR 1,000,000 per day, and a portion of which costs IDR 12,000 , with 66 portions sold out surely daily. This stall opens from 07.00 a.m.-01.00 p.m. local time. This batagor seller leases the stall at IDR 9,000,000 price per year. 
Thirdly, Kamboy photocopy and stationeries store has been leased by Ustadz Qodam, with sale volume of IDR 2,000,000 per day; five employees have been paid IDR 1,100,000 monthly. This 5x12 meter square building has been leased at IDR 45,000,000. Fourthly, YGYoung Generation store sells common shoes and clothing, with daily sale volume of IDR 500,000 and one employee. This 5 x 12 meter square building has been leased at the price as same as that of Kamboy store, IDR 45,000,000 per year. Thirdly, UMMY Collection store has been leased by $\mathrm{KH}$ Mursyidin, constituting the chairperson of $\mathrm{KH}$ Mursyidin, alumnus, and the founder of pesantren. The lease price is the same as that for other stall IDR 45,000,000 per year; the building is $5 \times 12$ meter square. This stall has mean daily sale volume of IDR 1,000,000 (a million rupiah) for weekday, and IDR 10,000,000 per day in two weeks around lebaran (Eid Fitri). It has two employees, each of which is paid IDR 800,000.

La Hamiku, as the chairperson of koperasi and director of business charity for the pesantren said that the profit coming from the pesantren's business unit, either managed directly or indirectly (through shophouse and stall leasing) has been used for developing the pesantren entirely, with different percentage. He said that $75 \%$ profit of direct business such as koperasi and canteen has been utilized for the two sectors development, and the rest of $25 \%$ has been used to support the pesantren's activity. It has also been used for supporting the celebration of pesantren's anniversary day, santri competitions and social activities. For example, it is used for giving reward or funding to the high-performing santris in the competition. Meanwhile, $80 \%$ of profit coming from indirect business has been spent for developing the physical building and infrastructure, while the rest of $20 \%$ has been used to pay the salary of educators. The canteens existing in the pesantren are categorized into direct pesantren business. Although it is not managed directly by the business charity division, however it is still under the director of business charity's supervision. 
In general, those lease the building belong to the big family of Pesantren Ummussabri or their close relative; for example, the ones who lease a building for beauty salon business, Toyib-Halal R-Q Food Stall, Ummy Collection Shophouse and Empang Paleppo' 99 food stalls. It is impossible for them not to have relation to the pesantren. For example, Mrs. Fiah's employee who is the seller of fried food (gorengan) in the pesantren has become the seller in the canteen since 1993. It indicates that she has worked as the canteen seller since the number of building was not as large as that now (2019). In addition, to get closer relationship between lessees and employees of the pesantren, they have participated in social activities organized by the pesantren. When the pesantren holds akbirussanah or the pesantren's anniversary, sport and science competitions and art performance activities, they usually support by sponsoring or giving reward for those get involved.

Providing space to their alumni creates the pesantren bigger and stronger in terms of education and business unit because the alumni build any form of cooperation to develop the pesantren. For example, Ummy Collection shophouse has been leased by one of pesantren's founders, $\mathrm{KH}$. Mursyidin, the great imam in mosque al-Kautsar and al-Alam. It indicates that despite his position as Syaikhul Ma'had for two periods he does not attempt to get leasing cost lower than other lessees pay (less than IDR $45,000,000)$, since they want to enlarge the pesantren. Another example is the establishment of Paleppo'99 food stall, located strategically in the downtown and intersection near Kendari mayor's office, Ministry of Religion's Regional Office, and Provincial District Attorney Office.

\section{Paleppo'99 Food Stall}

Empang Paleppo'99 or Paleppo'99 food stall has become a business unit managed by the $1997^{\text {th }}$ alumnus generation, La Rahama. The 
pesantren is very grateful with this business unit since the alumnus utilizes the land inundated with water which creates it more beautiful, cleaner, and tidier. In addition, to get income from land leasing, it can also give added-value, particularly because many people pass the pesantren through this way every day. For the first year, its sale volume reaches at least around IDR 1,000,000, with four employees. It means, when the sale volume is calculated monthly, this business is still profitable.

Table 1. The Financial Bookkeeping of Empang Paleppo'99

\begin{tabular}{|l|l|l|l|l|l|l|}
\hline $\begin{array}{l}\text { Sale } \\
\text { volume/ day }\end{array}$ & 30 days & $\begin{array}{l}\text { Paying the } \\
\text { wage of } 4 \\
\text { employees/ } \\
\text { month }\end{array}$ & $\begin{array}{l}\text { Business } \\
\text { financial ratio: } \\
40 \% \text { capital : } \\
60 \% \text { profit }\end{array}$ & Monthly profit & $\begin{array}{l}\text { Land leasing } \\
\text { cost/year }\end{array}$ & $\begin{array}{l}\text { Annual Net } \\
\text { Profit }\end{array}$ \\
\hline $1,000,000$ & 30.000 .000 & $4,800,000$ & $\begin{array}{l}12,000,000 \\
\text { (expenditure for } \\
\text { cooking menu) }\end{array}$ & $\begin{array}{l}13,200,000,- \\
(158,400,000 / \text { year })\end{array}$ & $50,000,000,-$ & $108,400,000$ \\
\hline
\end{tabular}

Source: interview with Abdul Makruf on March 28, 2019.

The name "Paleppo" has been selected, according to Abdul Makruf, because it is similar to the name of a city in Syria, "Aleppo". The founder wants this food stall (empang) to become as famous as "Aleppo" city before the civil war on 2016. Aleppo in Syria has been one of best ancient cities in the world with a variety of historical buildings. Even, some of buildings in this city have been announced officially to be the world's cultural heritage by UNESCO, for example, Masjid Umayyad (Umayyad mosque). This mosque was built in the period of khalifah al-Walid bin Abdul Malik and Bani Umayyah's reign. La Rahama, according to Abdul Makruf, of course acquired information on the beauty of Aleppo city from Instagram. He seemed to envision Empang Paleppo'99 to be as beautiful as Aleppo city as the shopping and souvenir centers for foreign tourists. Empang Paleppo'99 located in the downtown of Kendari, in which there is a square near the mosque, and equipped with public swimming pool. Meanwhile, 
traditional market inside has been intended to make it the heaven of cheap antiques with premium quality.

Furthermore, Abdul Makruf explains that Empang Paleppo'99 has been still less well-known, compared to other food stalls in Kendari which has been established longer. Not only located in strategic location, it also serves various menus and provides fresh water fishing pool for the customers. According to Muji, the chef of Paleppo'99, there are such menus as Paleppo-typical baked fish, complete baked rib, and other typical menus. In addition, this food stall also presents a comfy circumstance to be relaxed along with family and friends. Its price is of course affordable to lower-middle class of society that wants to enjoy high-quality meal, for example, a portion of complete package squid costs only IDR 25,000 and baked rib complete package costs IDR 30,000. This food stall with chic nuance also offers different circumstance, receives booking for such events as arisan (social gathering) and birthday party.

According to Abdul Makruf, this business plan to be developed in cooperation with many parties. There is a teacher in Madrasab Ummussabri, Afifi, who has also a business of producing Arabic calligraphy and beautiful gallery works, and designing public garden. In doing so, this food stall will be designed well by posting some Arabic calligraphy works to beautify the scenery and to promote the galleries. After the cooperation with the gallery, other cooperation would have been established with modern dancers and musicians coming from Kendari City. The management provides a space for the dancers to perform on Empang Paleppo'99 floor. They also create an event to attract the visitors by presenting musicians from Kendari City. Abdul Makruf as the one entrusted to manage this empang said that it is indeed leased with official document annually, and it will be extended according to the agreement between the lessee and the pesantren. He will be asked to help manage and be responsible for this successful business. 
The permission of establishing this business is of course because of the alumnus negotiation (La Rahama) (interview with Makruf).

\section{The Significance of Alumni Networks}

This study shows that business units are basically managed by the management which still has closer relation to the big family of the Pesantren Ummussabri, including those leasing shophouse. Although the employees can be non-alumni or the one not having close relation to pesantren, the lessee or the management of contract is usually coming from "insider" person. It is called "insider" borrowing the term suggested by La Hamiku, the chairperson of koperasi pesantren and the head of pesantren's business charity division. The lessee of land used for Empang Paleppo'99 (La Rahama), the lessee of Ummy Collection shophouse (KH. Mursyidin), and some lessees and the sellers in canteens in the pondok (Mrs. Fiah) are insiders. Mrs. Fiah has been the sellers since 1993. They lease land or cooperate with the pesantren purely for business purpose, as proved with contract agreement that can be extended annually, according to the agreement. The leasing cost is adjusted with the width of land and the facilities available.

The agreement established between parties is indeed not longer than one year, to maintain good relationship and to relieve the alumni or "insider" burden in leasing it. The business contract has been provided not merely for business purpose but also for maintaining good relationship and promoting the pesantren. The leasing cost for the shophouse leased by $\mathrm{KH}$ Mursyidin. Although he is one of the founders of the pesantren through GUPPI and serves as Syaikhul Ma'had, in term of leasing the shophouse he is considered as a "stranger", given leasing cost as much as that given to others, IDR 45,000,000 per year. If the cooperation is mutually profitable, 
it can be extended according to the agreement. Meanwhile, KH. Mursyidin also feels happy because the profit coming from shophouse leasing and its utilization reverts to the pesantren, $80 \%$ for constructing building and infrastructure and 20\% for the welfare of non-civil servant educators.

Borrowing Soekanto's (2000: 76-77) term, there are four types of relationship in each community: cooperation, competition, conflict, and accommodation. Social relation is the result of systemic interaction between two or more persons. The social relation will be existed when everyone can appropriately forecast the action that will come from others against him. Systemic interaction intended is the one occurring regularly and repeatedly with the same pattern (Spradley and McCurdy, 1975: 116). This interaction pattern is later called social relation which creates social network. The relationship established between the pesantren in the existing business unit emphasizes more on cooperation and accommodation. Cooperation can be seen from the lessee of land (e.g. Empang Paleppo'99) who can promote added-value to the land which formerly inundated with flood, in turn change it into the more beneficial as the fishing spot while enjoying the menu in the food stall (empang). In addition, another form is accommodation. It can be understood that La Rahama as the lessee of land then adorns a business of Paleppo'99 food stale, since he is an alumnus of the pesantren who pays attention to the the pesantren's progress, no longer serving as sponsor or donor but as an investor of productive business, with some of profit is taken aside to be donated to the pesantren.

In this study, the approach used is social network as an approach in anthropological study attempting to understand the form and function of social relationship in a complex community. Mitchell (1969: 1-2) explains that social network is a set of specific relations established in a group of people, the characteristics of which can be used to interpret the social behavior motives of those participating within. Social network is created 
within community because human beings cannot relate to all human beings existing. Relation is always limited to a certain number of people. Social network, according to Suparlan (1982: 35), is a grouping consisting of at least three persons, each of which has distinctive identity and connected to one and another through the social relations existing, so that through such social relation, they can be grouped into a social unit. In life reality, this social network is very complex and overlapping or intersecting.

Barness (1969) says that there are two social networks: comprehensive and partial social networks. The comprehensive social network is an entire network the individuals have involving many life context and aspects. Partial social network is the one the individuals have, limited to certain life sectors (e.g. political, economic, religious, and kinship networks). Considering this statement, the social relation between the lessee of land used for Empang Paleppo'99 and pesantren can be categorized into comprehensive relation. It can be proved that before leasing the land for establishing food stall business, La Rahama has long been the permanent donor and the alumnus of the pesantren. It means that La Rahama has been the part of the pesantren's big family before becoming the lessee for the food stall business. There is also partial social relation, for instance, the relation between the lessee of stall in front of the pesantren's cooperatives (Mr. Jajang) occurring only because the corresponding is bond to siomay and batagor Bandung outlet for economic interest.

In the relationship between the pesantren and the alumni as the lessees of shophouse or land, three types of social relation orders are found: firstly, structural order in which people's behavior is interpreted into the terminology of actions corresponding to the role and position occupied in a company, family, and political party; secondly, categorical order, in which people's behavior in unstructured situation can be interpreted into stereotype term such as class, race, and ethnic; and thirdly, personal order 
in which people's behavior in both structured and unstructured situations can be interpreted into the term of inter-individual relations in a group or the relationship between a group and another (Mitchell, 1969: 10).

In the context of the pesantren and alumni network, constituting the lessees of business unit in pesantren-owned shophouse, only two forms of relations applies: structural order and individual order. Meanwhile, categorical order is not apparent. It can be understood that the social relation between pesantren and KH. Mursyidin as the lessees of shophouse named "Ummy Collection" is called structural order, because K.H. Mursyidin as the lessee is structurally assigned to be Syaikhul Ma'had in pesantren, while the pesantren represented by the administrator of foundation as the receiver of shophouse leasing cost which is mandated fully to use the result of shophouse leasing to develop the pesantren and supporting infrastructure. The rest is leaned to personal order, for instance, the relation between the lessee of Empang Paleppo'99 and the pesantren occurs because both parties cooperate volitionally. However, it is not merely for business purpose, because institutionally, the pesantren is really helped with the presence of Empang Paleppo'99 business.

Analyzing from the objective of social relation to create social network, there are three types of network. Firstly, power network is the one composed of social relations with political content. In power network, the configuration of interrelation between actors within it is intentional in nature. Such network arises when the achievement of targeted objectives requires collective action and the configuration of interrelation between actors that is permanent in nature. Secondly, interest network is the one in which social relations composing have interest content. This interest network is composed of meaningful relations in certain or specific objectives. The structure arising from this type of social network is transient and arbitrary in nature. Thirdly, feeling network (sentiment) is the one 
composed of feeling content, in which the social relations themselves become the objective and social action. The structure composed of these feeling relations tends to be well-established and permanent. The social relations created usually tend to be close and continuous ones. The actors tend to like or dislike others in social network. Therefore, a relatively strong control arises between the actors (Agusyanto, 1996: 19-19).

Reflecting to the above theory, in the case of Pesantren Ummusabri, its alumni leads to have feeling networks. This network has been built by cooperating in utilizing shophouse. Some of them are related to service, Muslim fashion, food stall, and beauty salon businesses. Furthermore, feeling network also applies since nearly all lessees of business shophouse around the pesantren comes from the alumni or big family of the pesantren. Considering this fact, the pesantren does not need to worry because its individual relations are those who know exactly the pesantren. They will clarify something wrong quickly and help correct it well and rightly. This relation model course defined as the pesantren's massive form of socialization.

The cooperation between the pesantren and lessees is not far different from what has been said by Wolf (1978: 10-15) that an individual's friendship relation is divided into two: expression/emotional and instrumental relations. Emotional relation is the relationship between two persons, each of which satisfies another emotional need. Meanwhile, the instrumental friendship relation is the friendship relation which is not intended to access resource, either natural or social. However, every member applies dyadic relation, the one established between two persons interacting with each other and direct in nature, interpersonal bond, and requiring the presence of certain obligation. In the case of cooperation between the pesantren and Ummy Collection shophouse and Empang Paleppo'99, it can belong to emotional relation, in which both parties feel 
satisfied with their need fulfillment. It can also belong to instrumental relation because the lessees that are enable to access facilities and social resource. Furthermore, this instrumental relation requires a participant to be the sponsor of another, and the one connected to another. It implies that the lessees may come from non-alumni or have never been the santri of Ummussabri, but they become the lessee because their children become the students in the madrasah under the pesantren, e.g. the lessee of shophouse for beauty salon business. In this case, the owner of beauty salon has relation or connection in the attempt of getting the resource.

\section{Conclusion}

The strategy of alumni network of the Pesantren Ummussabri in improving the economics of this institution relates to how the pesantren cooperates with alumni and vice versa, in terms of managing the business units. The business unit has been managed directly includes koperasi pesantren and canteens in the pesantren. Koperasi has been managed and led by the head of business charity division. Meanwhile, there are nine canteens in the pesantren selling any type of products, particularly food. The number of business which has not managed directly are many, siomay-batagor seller and canteen for the santri Halal-Toyib R-Q. There are four shophouses with substantial leasing cost, including Empang Paleppo'99. All incomes coming from shophouse leasing are used for physical development (80\%), for educator welfare (20\%) and operational cost. Meanwhile the income of cooperatives has been used for cooperatives development (75\%) and for social activities in the pesantren (25\%), including akhirussanah event by giving reward for the high-performance students. In turn, the participation of pesantren alumni in reinforcing the pesantren's economy is very visible. 


\section{References}

Agusyanto, Ruddy. (1996). Dampak Jaringan -jaringan Sosial dalam Organisasi: Kasus PAM Jaya, DKI Jakarta,” Tesis, Jakarta: Program Pascasarjana UI.

Azizah, Siti Nur. (2014). Pengelolaan Unit Usaha Pesantren Berbasis Ekoproteksi. Ekbisi, IX, (1), 103-115.

Barness, J.A. (1969). Network and Political Process," dalam Mitchell J. Clyde (ed.), Social Network in Urban Situation: Analysis of Personal Relationship in Central Africa Town. Manchester: Manchester University Press.

Bawono, Anton. (2018). Creative Economic Development of Pesantren. Shirkah-Journal of Economic and Business, 3 (1), 25-47. doi:10.22515/ shirkah.v3i1.178.

Fauzi, Ahmad. (2017). Pengembangan Ekonomi Islam di Pesantren Jawa Timur, Al-Ulum, 17 (1), June, 100-119.

Haryono, Tri Joko S. (2019). Jaringan Sosial Migran Sirkuler: Analisis tentang Bentuk dan Fungsi, retrieved from http://journal.unair.ac.id/ filerPDF/Jaringan\%20Sosial\%20Migran\%20Sirkuler.pdf

Isbah, M Falikul. 2016. "Examining the Socio-Economic Role of Islamic Boarding Schools( Pesantren ) in Indonesia," A thesis in fulfilment of the requirements for the degree of Doctor of Philosophy, UNSW Australia, School of Humanities and Social Sciences UNSW Canberra, June retrieved http://unsworks.unsw.edu.au/fapi/datastream/unsworks:39636/ SOURCE02?view=true

Jalil, Abdul.(2017). Mempromosikan Multikulturalisme pada Program "Rentak Pelangi Bumi Anoa" di Radio Republik Indonesia Kendari Sulawesi Tenggara. Prosiding Simposium Internasional Bahasa-Bahasa Lokal Nasional dan Global, Universitas Halu Oleo in collaboration with Asosiasi Peneliti Bahasa-Bahasa Lokal pada 27-29 September 2016, published on 07 Januari 2017. 
Lugina, Ugin. (2017). Pengembangan Ekonomi Pondok Pesantren Di Jawa Barat.Risâlah, Jurnal Pendidikan dan Studi Islam, 4 (1), 53-64. doi: 10.5281/zenodo. 1227465 .

Mitchell, J. Clyde. (1969). Social Networks in Urban Situation: Analysis of Personal Relationships in Central Africa Town. Manchester: Manchester University Press.

Mu'ammar. (2014). Pilar-Pilar Peradaban Pesantren: Potret Potensi danPeran Pesantren Sebagai Pusat Peradaban. Jurnal Madaniyah, VII (8), 277-299.

Mursyid.(2011). Dinamika Pesantren dalam Perspektif Ekonomi. Jurnal Millah, XI (1), 171-187.

Nadzir, Mohammad. (2015). Membangun Pemberdayaan Ekonomi Di Pesantren. Jurnal Economica, VI (1), 37-56.

Suharti, Lieli\& Ferrinela.(2012). Studi Penelusuran Terhadap Alumni Program Studi Manajemen Fakultas Ekonomi Dan Bisnis Universitas Kristen Satya Wacana, Proceeding Pekan Ilmiah Dosen FEB UKSW, 14 (12), 231-248.

Soekanto, Soerjono. (2000). Sosiologi Suatu Pengantar. Jakarta: PT. Grafindo Persada.

Spradley, James P. \& McCurdy, David. (1975). The Culture Experience: Ethnography in Complex Society. Chicago: Science research Associate. Suparlan, Parsudi. (1982). Jaringan Sosial in Media IKA Februari, 8 (X), 29-47, Jakarta: Ikatan Kekerabatan Antropologi Fakultas sastra UI.

Trisnawati, Ira. (2017). Pengembangan Pondok Pesantren Melalui Peningkatan SDM (Studi Multi Kasus di Pesantren Ummusshabri dan Pesantren Darul Mukhlisin Kendari Sulawesi Tenggara). Tesis UIN Malang.

Wolf, Eric.( 1978). Kinship, Friendship and Patron Client Relationship in Michael Banton (ed.), The Social Anthropology of Complex Societes. London: Tovistock Pub. 


\section{Other sources}

\section{Internet:}

Sekilas Pesantren Ummussabri lihat https:/ummushbri.wordpress.com/about, retrieved from 28 Februiari 2018.

\section{Interview:}
a. La Hamiku (interview, 9 March 2019).
b. Istiqomah (interview, 29 March 2019).
c. Kamri (interview, 4 April 2019).
d. Muli (interview, 4 April 2019).
e. Zakiyyah (interview, 4 April 2019).
f. Fiah (interview, 4 April 2019).

\section{Appendix 1. Business Units of Pesantren Ummussabri}

\begin{tabular}{|c|c|c|c|c|c|c|}
\hline Business Type & $\begin{array}{l}\text { Business } \\
\text { Status }\end{array}$ & Land/Stall Ownership status & Sale volume & Leasing value & Informant & $\begin{array}{c}\text { Interview } \\
\text { period }\end{array}$ \\
\hline $\begin{array}{l}\text { Kantin Santri } \\
\text { (canteen for } \\
\text { santri) R-Q } \\
\text { Halal Toyib }\end{array}$ & $\begin{array}{l}\text { Leased by } \\
\text { alumni Mrs. } \\
\text { Hj. Nuraini }\end{array}$ & $\begin{array}{l}\text { Belonging to pesantren, } 4 \times 4 \\
\text { meter wide, located in front of } \\
\text { the pesantren's cooperatives }\end{array}$ & $\begin{array}{l}\text { IDR. 700,000,- } \\
\text { per day }\end{array}$ & $\begin{array}{l}\text { IDR. } \\
8,000,000,- \\
\text { per year }\end{array}$ & Istiqomah & $\begin{array}{l}29 \text { March } \\
2019\end{array}$ \\
\hline $\begin{array}{l}\text { Batagor- } \\
\text { Siomay } \\
\text { Bandung }\end{array}$ & $\begin{array}{l}\text { Leased by Mr. } \\
\text { Jajang }\end{array}$ & \begin{tabular}{|l|} 
Belonging to pesantren, $3 \times 3$ \\
m wide, located in front of the \\
pesantren's cooperatives.
\end{tabular} & $\begin{array}{l}\text { IDR. } 800,000- \\
1,000,000 \\
\text { Per day }\end{array}$ & $\begin{array}{l}\text { IDR. } \\
9,000,000,- \\
\text { Per day }\end{array}$ & Jajang & $\begin{array}{l}\text { 29 March } \\
2019\end{array}$ \\
\hline $\begin{array}{l}\text { Ummussabri } \\
\text { Cooperatives } \\
\text { of Kendari }\end{array}$ & $\begin{array}{l}\text { Belongs to } \\
\text { Pesantren }\end{array}$ & $\begin{array}{l}\text { Belonging to pesantren, } 5 \times 19 \\
\text { meter wide }\end{array}$ & $\begin{array}{l}\text { IDR. } \\
40,000,000,- \\
\text { Per week }\end{array}$ & IDR. 0 & Erna & 5 April 2019 \\
\hline $\begin{array}{l}\text { Clothing } \\
\text { and Uniform } \\
\text { Procurement } \\
\text { Unit } \\
\end{array}$ & $\begin{array}{l}\text { Belongs to } \\
\text { Pesantren }\end{array}$ & $\begin{array}{l}\text { Belonging to pesantren,: } 5 \times 19 \\
\text { meter wide }\end{array}$ & $\begin{array}{l}\text { IDR. } 800,000 / \\
\text { month }\end{array}$ & IDR. 0 & Yuli & 8 April 2019 \\
\hline $\begin{array}{l}\text { Photocopy and } \\
\text { stationeries } \\
\text { shop }\end{array}$ & $\begin{array}{l}\text { Leased by } \\
\text { Qodam }\end{array}$ & $\begin{array}{l}\text { Belonging to pesantren,: } 5 \times 19 \\
\text { meter wide }\end{array}$ & $\begin{array}{l}\text { IDR. 2,000,000/ } \\
\text { day }\end{array}$ & $\begin{array}{l}\text { IDR. } \\
45,000,000 / \\
\text { year }\end{array}$ & Muli & 8 April 2019 \\
\hline $\begin{array}{l}\text { "YG-Young } \\
\text { Generation" } \\
\text { store }\end{array}$ & $\begin{array}{l}\text { Leased by } \\
\text { Ernida }\end{array}$ & $\begin{array}{l}\text { Belonging to pesantren, } 5 \times 19 \\
\text { meter wide }\end{array}$ & $\begin{array}{l}\text { IDR. 500,000/ } \\
\text { day }\end{array}$ & $\begin{array}{l}\text { IDR } \\
45,000,000\end{array}$ & & 8 April 2019 \\
\hline $\begin{array}{l}\text { "Ummy } \\
\text { Collection" } \\
\text { store }\end{array}$ & $\begin{array}{l}\text { Leased by K.H } \\
\text { Mursidin }\end{array}$ & $\begin{array}{l}\text { Belonging to pesantren, } 5 \times 19 \\
\text { meter wide }\end{array}$ & $\begin{array}{l}\text { IDR. 1,000,000/ } \\
\text { day }\end{array}$ & $\begin{array}{l}\text { IDR. } \\
45,000,000\end{array}$ & Zakiyah & 8 April 2019 \\
\hline
\end{tabular}

Vol. 4 No. 2, May - August 2019 


\begin{tabular}{|c|c|c|c|c|c|c|}
\hline $\begin{array}{l}\text { Canteen inside } \\
\text { Pondok } \\
(8 \text { stalls })\end{array}$ & $\begin{array}{l}\text { Leased by } 8 \\
\text { persons }\end{array}$ & $\begin{array}{l}\text { Belonging to pesantren, each } \\
\text { building is } 4 \times 5 \text { meter wide }\end{array}$ & $\begin{array}{l}\text { IDR. 500,000/ } \\
\text { day }\end{array}$ & $\begin{array}{l}\text { IDR. } \\
9,000,000,-x \\
8 \text { stalls = IDR. } \\
72,000,000 / \\
\text { year }\end{array}$ & $\begin{array}{l}\text { Fiah/Fried } \\
\text { Food stall }\end{array}$ & 8 April 2019 \\
\hline $\begin{array}{l}\text { "Paleppo'99" } \\
\text { Food stall }\end{array}$ & $\begin{array}{l}\text { Leased by } \\
\text { alumni : La } \\
\text { Rahama }\end{array}$ & $\begin{array}{l}\text { Belonging to pesantren,: } 50 \mathrm{x} \\
60 \text { meter wide }\end{array}$ & $\begin{array}{l}\text { IDR. 800,000,- } \\
\text { per day }\end{array}$ & $\begin{array}{l}\text { IDR. } \\
50,000,000,- \\
\text { per year }\end{array}$ & $\begin{array}{l}\text { Abdul } \\
\text { Makruf }\end{array}$ & $\begin{array}{l}28 \text { March } \\
2019\end{array}$ \\
\hline Beauty Salon & $\begin{array}{l}\text { Leased by } \\
\text { a student } \\
\text { guardian }\end{array}$ & $\begin{array}{l}\text { Belonging to pesantren, } 4 \times 7 \\
\text { meter wide }\end{array}$ & IDR.200,000,- & $\begin{array}{l}\text { IDR. } \\
12,000,000,-\end{array}$ & $\begin{array}{l}\text { La } \\
\text { Hamiku }\end{array}$ & 4 April 2019 \\
\hline
\end{tabular}

Vol. 4 No. 2, May - August 2019 


\section{Shirkah Author Guidelines}

Shirkah currently offers two routes to submit manuscripts. We highly recommend to submit the articles which are made using OJS (Open Journal System). Feel free register as author soon through visiting http:// shirkah.or.id/index.php/home/user/register. The authors may directly send their manuscripts, along with their resume, to shirkahiainsurakarta@ gmail.com. Please prepare your manuscripts, using following guidelines:

1. Manuscript must be written in English. Submitted articles should not have been published or be under review for publication with another journal.

2. Manuscript's length is about $15-20$ pages, typed in one-half spaced on A4-paper size.

3. Manuscript must include an $150-200$ word abstract and keywords.

4. Manuscript must be arranged as follows: Title, Name of Author, E-mail address, Abstract, Keywords, Introduction (including method if any), Discussion, Conclusion, References.

5. Manuscript's titles not more than ten words.

6. Manuscript must be submitted in Microsoft Word or RTF.

7. Arabic words should be transliterated according to the style of International Journal of Middle Eastern Studies.

8. Manuscript references are preferably derived from the up-to-date references.

9. The author's resume should be submitted separately, consisting of at least full name, institutional address, phone number, areas of studies, and recent publications (if any).

10. Shirkab use APA Style 6th edition (2010) as reference format writing. We suggest the use of a reference manager software such as Mendeley, Zotero, and Endnote at templating the citation style. APA Style to be used is as follows: 


\section{Book with single author}

Swann, G. M. Peter. (2014). The Economics of Innovation an Introduction. Cheltenhum \& Northampton: Edward Elgar.

in-text citation: (Swann, 2014)

\section{Articles in reference books}

Alatas, S. F. (2006). Islam and the Science of Economics in Abu Rabi', I.M. The Blackwell Companion to Contemporary Islamic Thought. USA: Willey-Blackwell (pp. 587-606).

in text citation: (Alatas, 2006)

\section{E-Book}

Hackett, Rosalind (2007). "Religous Dimentions of War and Peace: Introduction.” Dalam Gerrie ter Haar dan Yoshio Tsuruoka (Ed.), Religion and Society: An Agenda for the 21st Century (h. 3-6). Retrieved from http:// brill.nl.

in text citation: (Hackett, 2006)

\section{Master's thesis, from a commercial database}

McNieI, D. S. (2006). Meaning through narrative: A personal narrative discussing growing up with an alcoholic mother (Master's thesis). Available from ProQuest Dissertations and Theses database. (UMI No. 1434728)

in text citation: (Mc Niel, 2006)

\section{Doctoral dissertation, from an institutional database}

Adams, R. J. (1973). Building a foundation for evaluation of instruction in higher education and continuing education (Doctoral dissertation). Retrieved from http://www.ohiolink.edu/etd/

in text citation: (Adams, 1973) 


\section{Doctoral dissertation, from the web}

Bruckman, A. (1997). MOOSE Crossing: Construction, community, and learning in a networked virtual world for kids (Doctoral dissertation, Massachusetts Institute of Technology). Retrieved from http:/www-static. cc.gatech.edu/--asb/thesis/

in text citation: (Bruckman, 1997)

\section{Journal article with No DOI}

Bourkhis, K., and Nabi, M. S. (2013). Islamic and conventional banks' soundness during the 2007-2008 financial crisis. Journal Metrics, 22(2), 68-77.

in-text citation: (Bourkhis \& Nabi, 2013).

\section{Journal article with DOI}

Ichwan, M. (2012). The Local Politics Of Orthodoxy: The Majelis Ulama Indonesia in the Post-New Order Banten. Journal Of Indonesian Islam, 6(1), 166-194. doi:http://dx.doi.org/10.15642/JIIS.2012.6.1.166-194

In text citation : (Ichwan, 2012)

\section{Abstract as citation}

Hasan, N. (2012). Islamist Party, Electoral Politics And Da'wah Mobilization Among Youth : The Prosperous Justice Party (PKS) in Indonesia. Journal of Indonesian Islam, 6(1), 17-47. Abstract from http:// jiis.uinsby.ac.id/index.php/jiis/article/view/97

in text citation : (Hasan, 2012)

\section{Mass media article}

Sahal, Akhmad (2014, March 2). Kiai Sahal dan Realisme Fikih.Tempo Magazine, p. 120.

in text citation : (Sahal, 2014) 


\section{Research report}

Fisher, B. S., Cullen, F. T., \& Turner, M. G. (2000). The Sexual Victimization of College Women. Research Report.

in text citation : (Fisher, Cullen, Turner, 2000)

\section{Monograph}

Routray, Bibhu Prasad (2013), National Security Decision-Making in India (RSIS Monograph No. 27). Singapura: Rajaratnam School of International Studies.

in text citation : (Routray, 2013)

\section{Proceeding article}

Sudibyakto, Hizbaron, D.R., \& Jati, R (Ed.) (2009), Proceeding International Seminar Disaster Theory, Research and Policy. International seminar held by Sekolah Pascasarjana, Universitas Gajahmada, Yogyakarta, 8-9 Desember 2009.

in text citation : (sudibyakto and Jati, 2009)

\section{Paper conference/seminar/symposium}

Janutama, Herman Sinung (2011). "Kraton dan Hubungan Antar Agama." Paper presented in Seminar Kraton dan Panatagama held by Center for the Study of Islam and Social Transformation (CISForm), Yogyakarta, 17 November.

in text citation :(Janutama, 2011)

\section{Online article in web}

Shiva, (2006, February). Bioethics: A Third World Issue. Native-web. Diperoleh dari http://www.nativeweb.org/ pages/legal/shiva.html

in text citation : (Shiva, 2006) 


\section{Online research report}

Kessy, S. S. A., \& Urio, F M. (2006). The contribution of microfinance institutions to poverty reduction in Tanzania (Research Report No. 06.3). Retrieved from Research on Poverty Alleviation website: http://www. repoa.or.tz /documents_storage/Publications/Reports/06.3_Kessy_and_ Urio.pcif

in text citation : (kessy and urion, 2006)

\section{Holy book}

Qur an, $2(25)$

In text citation : (Q. al-Baqarah 2:25).

\section{Encyclopaedia}

Graycar, Adam (1992). Social Welfare Policy. Dalam Mary Hawkesworth dan Maurice Kogan (Ed.), Encyclopedia of Government and Politics (Vol. 1). London: Routledge.

in text citation : (Graycar, 1992)

\section{Interview}

Sultan Hamengkubuwono X (interview, 2011, April 19)

in text citation: (Hamengkubuwono, 2011)

\section{Documentary film}

Steijlen, Fridus (2008). A Day in the Life of Indonesia [documentary film, 58 minutes]. Leiden: KITLV Press.

in text citation : (Steijlen, 2008) 
Vol. 4 No. 2, May - August 2019 